\title{
PERFORMA BUDIDAYA UDANG VANAME (Litopenaeus vannamei) SEMI INTENSIF DI DESA PURWOREJO KECAMATAN PASIR SAKTI KABUPATEN LAMPUNG TIMUR
}

\author{
Luqman Hakim*1, Supono, Yudha T. Adiputra*2, dan Sri Waluyo*3 \\ DOI: http://dx.doi.org/10.23960/jrtbp.v6i2.p691-698
}

\begin{abstract}
Pacific white shrimp (Litopenaeus vannamei) is new species were culture to replace tiger shrimp (Penaeus monodon) in Purworejo village, Pasir Sakti sub-district of East Lampung residence. This study was purposed to investigate culture performances of Pacific white shrimp in semi intensive system in two farmer groups. Eight ponds with $\pm 2100 \mathrm{~m}^{2} /$ ponds and density of $60 \mathrm{ind} / \mathrm{m}^{2}$ was used for this study. Results showed that Pacific white shrimp performances was different among two farmer groups. Sido Makmur group showed better performance compared to Lestari Gemilang with showed of ponds productivity 1337,8 $\mathrm{kg}$ and $1330,3 \mathrm{~kg}$, respectively. FCR and SR among two groups also showed different, there were 1,88 to 2,39 and $86,95 \%$ to $63,3 \%$, respectively. High mortality after WSSV infection was decreased pond productivity. Water quality parameters such as ammonia $(0,029-0,031 \mathrm{ppm})$ and light density $(<40 \mathrm{~cm})$ were not suitable for shrimp culture impacted to pond productivity. WSSV infection and water quality parameters had corellation to pond performances.
\end{abstract}

Keywords: Pacific white shrimp, semi intensive, productivity, new ponds area, East Lampung

\section{Pendahuluan}

Potensi lahan untuk pengembangan budidaya tambak khususnya udang di Provinsi Lampung mencapai 61.200 ha $(\mathrm{BI}$, 2015). Lampung menjadi penyumbang terbesar produksi udang vaname (Litopenaeus vannamei) nasional tahun 2013 yaitu sebesar 72.051 ton (KKP, 2013). Produksi tersebut sebagian besar diperoleh dari kegiatan budidaya dengan teknologi semi intensif sampai dengan intensif yang tersebar di kabupaten-kabupaten yang berada di pesisir pantai seperti Tulang Bawang, Lampung Selatan, Tanggamus dan Pesawaran. Sedangkan di Kabupaten Lampung Timur, nilai produksi udang vaname masih tergolong rendah. Rendahnya produksi udang vaname daerah tersebut disebabkan belum masuknya teknologi budidaya udang vaname

\footnotetext{
${ }^{1}$ E-mail: kang.luqman30@gmail.com

${ }^{2}$ Jurusan Perikanan dan kelautan, Fakultas Pertanian, Universitas Lampung

Jl. Jl.Prof.S.Brodjonegoro No.1 Gedong Meneng Bandar Lampung 35145

${ }^{3}$ Jurusan Teknik Pertanian, Fakultas Pertanian, Universitas Lampung

J1. J1.Prof.S.Brodjonegoro No.1 Gedong Meneng Bandar Lampung 35145
} 
dan sebagian besar area pertambakan yang ada merupakan tambak udang windu (Penaeus monodon) dengan teknologi budidaya tradisional yang dikelola pribadi dengan modal terbatas.

Di antara kecamatan yang ada di Lampung Timur dengan potensi pengembangan budidaya udang vaname adalah Kecamatan Labuhan Maringgai dan Pasir Sakti. Di Kecamatan Pasir Sakti khususnya di Desa Purworejo, budidaya udang vaname berjalan dalam kurun waktu 2-3 tahun terakhir. Teknologi budidaya perlu ditingkatkan guna menghasilkan produksi udang yang tinggi. Dengan latar belakang tambak masyarakat, teknologi yang memungkinkan untuk diterapkan adalah teknologi semi intensif. Teknologi ini dapat dilakukan oleh petambak dengan menghimpun modal dan tenaga dari anggota kelompok pembudidaya, sehingga kegiatan budidaya lebih mudah dijalankan. Terbatasnya data mengenai budidaya udang vaname di Desa Purworejo Kecamatan Pasir Sakti, menjadi dasar perlu dilakukannya penelitian mengenai performa budidaya udang vaname semi intensif di desa tersebut. Tujuan penelitian ini adalah untuk mengetahui performa budidaya udang vaname semi intensif di Desa Purworejo, Kecamatan Pasir Sakti, Kabupaten Lampung Timur. Data yang diperoleh diharapkan dapat menjadi acuan dan sumber informasi bagi masyarakat dalam menunjang keberhasilan kegiatan budidaya udang vaname di daerah tersebut dan daerah lain pada umumnya.

\section{Metode}

Penelitian dilaksanakan selama 120 hari pada tambak percontohan udang vaname yang dikelola dengan teknologi semi intensif di Desa Purworejo pada dua kelompok tani yaitu Sido Makmur dan Lestari Gemilang. Data penelitian diperoleh dengan mengikuti semua aktifitas budidaya udang di tambak, studi literatur, observasi dan wawancara dengan petambak.

Petakan tambak pemeliharaan berjumlah 8 petak dengan luas masing-masing petak $\pm 2100 \mathrm{~m}^{2}$. Empat petak tambak merupakan tambak Kelompok Sido Makmur (Petak B1-B4) dan empat petak tambak merupakan tambak Kelompok Lestari Gemilang (Petak K1-K4). Air pemeliharaan berasal dari dari saluran air yang bermuara ke laut dan telah diendapkan dalam petak tandon. Untuk pembentukan warna air dilakukan pemupukan menggunakan urea (N 46\%) dengan dosis 0,5 ppm dan fermentasi dedak. Sedngkan untuk mempertahankan warna air dan pembentukan bakteri yang menguntungkan digunakan probiotik yang mengandung bakteri Bacillus sp., Pseudomonas sp., Nitrosomonas sp., Aerobacter sp., dan Nitrobacter sp. Setelah air pemeliharaan siap, selanjutnya dilakukan penebaran benih udang. Benih udang vaname PL-10 berasal dari panti benih PT. Biru Laut Khatulistiwa (BLK) dan ditebar dengan kepadatan 60 ekor $/ \mathrm{m}^{2}$.

Pada awal masa pemeliharaan sampai dengan pengambilan contoh udang pertama, pakan diberikan berdasarkan metode blind feeding program. Setelah pengambilan 
contoh udang pertama, pakan diberikan berdasarkan kebutuhan udang (demand feeding program). Pakan yang diberikan disesuaikan dengan bukaan mulut udang dengan persentase 1-10\%. Pakan yang digunakan memiliki kandungan protein 28-30 \%, kadar air $12 \%$, lemak $5 \%$ dan serat $4 \%$. Sebagai suplemen tambahan, pakan dapat juga dicampur dengan vitamin dan probiotik.

Pengambilan contoh udang dilakukan setelah umur pemeliharaan 35 hari pada waktu pagi hari. Pengambilan contoh dilakukan menggunakan jala dengan rentang waktu 7 hari sekali. Tujuan pengambilan contoh adalah untuk menduga populasi dan untuk mengetahui perkembangan udang yang dibudidaya sebagai acuan untuk menentukan sikap saat ditemukan masalah pada udang.

Untuk mempertahankan kualitas air terutama akibat amoniak $\left(\mathrm{NH}_{3}\right)$ dan $\mathrm{H}_{2} \mathrm{~S}$, setiap pekan dilakukan penebaran probiotik yang mengandung bakteri Rhodobacter $\mathrm{sp}$ dan Rhodococcus sp dengan dosis 0,5-1 ppm. Pengamatan penyakit hanya sebatas pengamatan visual pada kondisi udang di tambak dengan melihat gejala klinis yang mungkin timbul saat pengambilan contoh atau saat melakukan pengamatan keliling petakan tambak.

Setelah berat rata-rata udang mencapai ukuran yang sudah diterima di pasar, selanjutnya dilakukan panen sebagian (parsial). Tujuan panen parsial adalah mengurangi padat tebar, mengurangi penggunaan pakan, dan hasil penjualan dapat digunakan untuk pembelian pakan guna memenuhi kebutuhan pakan pada hari pemeliharaan yang tersisa sampai dengan tercapainya ukuran udang yang dikehendaki. Setelah ukuran yang dikehendaki tercapai, selanjutnya dilakukan panen total.

Parameter utama yang diamati pada penelitian ini adalah tingkat pertumbuhan, kelulushidupan (survival rate-SR) udang, biomasa dan konversi pakan (feed conversion ratio-FCR) yang diperoleh dari pengambilan contoh setiap 7 hari sekali. Sedangkan parameter penunjangnya adalah fisika-kimia air meliputi oksigen terlarut, $\mathrm{pH}$, suhu, salinitas, kecerahan dan ammonia yang diukur setiap 7 hari sekali. Data yang diperoleh dari hasil penelitian kemudian dianalisis menggunakan uji deskriptif untuk mendapatkan gambaran yang utuh mengenai keadaan di lokasi penelitian.

\section{Hasil dan Pembahasan}

\section{Pertumbuhan}

Berat udang rerata selama masa budidaya dapat dilihat pada Tabel 1 . Udang mengalami pertambahan berat tubuh seiring bertambahnya umur pemeliharaan. Namun di tambak B2 tidak didapatkan data pertumbuhan karena terjadi serangan penyakit white spot syndrome virus (WSSV) yang menyebabkan kematian pada udang di umur pemeliharaan 22 hari. Berat udang saat pengambilan contoh pertama di semua petak sebesar 1,62,84 gr dengan hasil terendah di petak K4 dan hasil tertinggi di B3. Nilai pengambilan contoh tersebut berada di bawah target yang ditetapkan berdasarkan blind feeding program yaitu sebesar 3 gr. 
Tabel 1. Berat udang rerata pada masing-masing petak tambak

\begin{tabular}{|c|c|c|c|c|c|c|c|c|}
\hline \multirow{2}{*}{$\begin{array}{c}\text { Day Of } \\
\text { Culture } \\
\text { (Hari) }\end{array}$} & B1 & B2 & B3 & B4 & K1 & K2 & K3 & K4 \\
\hline & $\begin{array}{c}\text { ABW } \\
\text { (gr) }\end{array}$ & $\begin{array}{c}\text { ABW } \\
\text { (gr) }\end{array}$ & $\begin{array}{c}\text { ABW } \\
\text { (gr) }\end{array}$ & $\begin{array}{c}\text { ABW } \\
\text { (gr) }\end{array}$ & $\begin{array}{c}\text { ABW } \\
\text { (gr) }\end{array}$ & $\begin{array}{c}\text { ABW } \\
\text { (gr) }\end{array}$ & $\begin{array}{c}\text { ABW } \\
\text { (gr) }\end{array}$ & $\begin{array}{c}\text { ABW } \\
\text { (gr) }\end{array}$ \\
\hline 35 & 2,8 & - & 2,84 & 1,92 & 1,78 & 1,73 & 1,78 & 1,6 \\
\hline 42 & 2,72 & - & 2,45 & 2,65 & 2,54 & 2,63 & 2,31 & 2,3 \\
\hline 49 & 3,6 & - & 3,4 & 3,0 & 3,25 & 3,5 & 3,25 & 3,3 \\
\hline 56 & 4,5 & - & 4,8 & 6,2 & 5,0 & 4,7 & 5,0 & 5,6 \\
\hline 63 & 6,9 & - & 6,3 & 5,5 & 6,6 & 5,92 & 7,3 & 5,83 \\
\hline 70 & 7,2 & - & 7,6 & 7,7 & 7,8 & 7,3 & 7,9 & 7,8 \\
\hline 77 & 9,79 & - & 9,3 & 9,4 & 9,4 & 8,73 & 9,3 & 9,1 \\
\hline 84 & 11,7 & - & 11,6 & 12,3 & 10,4 & 11,1 & 11,1 & 10,4 \\
\hline 91 & 12,98 & - & 13,88 & 12,72 & 11,79 & 12,8 & 13,88 & 12,7 \\
\hline 98 & 15,38 & - & 15,64 & 15,68 & 15,6 & 15,43 & 15,11 & 15,3 \\
\hline 105 & 17,41 & - & 18,91 & 18,18 & 16,94 & 17,41 & 18,2 & 16,3 \\
\hline 112 & 20,4 & - & 19,6 & 19,23 & - & 19,23 & 18,8 & 18,8 \\
\hline 121 & & - & & & _. & - & _. & 22,7 \\
\hline
\end{tabular}

Pada masa awal pemeliharaan, kondisi air keseluruhan petak budidaya sebelum penebaran benih berwarna bening. Hal ini menunjukkan plankton di perairan mati, padahal beberapa hari sebelum penebaran warna air tambak sudah terbentuk. Kondisi plankton yang mengalami kematian disebabkan oleh kurang maksimalnya persiapan air pemeliharaan sehingga mengakibatkan masuknya spesies kerang-kerangan Mytilus sp. Keberadaanya menjadi pesaing dalam konsumsi oksigen dan plankton, karena kerang-kerangan merupakan filter feeder yang menghisap air kemudian menyaring plankton untuk dijadikan makanan.
Pada pengambilan contoh pertumbuhan ke 2, di petak B1 dan B3 justru mengalami penurunan bobot tubuh udang (Gambar 1 dan 2), sedang di petak lain mengalami kenaikan. Penurunan bobot udang juga terjadi pada pengambilan contoh ke 5 di petak tambak B4. Kemungkinan yang menyebabkan turunnya bobot udang saat pengambilan contoh adalah adanya kesalahan saat pengambilan contoh. Pertumbuhan udang terus meningkat seiring bertambahnya umur pemeliharaan dengan rerata tingkat laju pertumbuhan harian sebesar 0,20$0,24 \mathrm{gr} /$ hari (Tabel 2).

Tabel 2. Lama pemeliharaan dan berat akhir udang

\begin{tabular}{cccccccc}
\hline \multirow{2}{*}{ Parameter } & \multicolumn{7}{c}{ Petak Tambak } \\
\cline { 2 - 8 } & B1 & B3 & B4 & K1 & K2 & K3 & K4 \\
\hline Umur Pemeliharaan (hari) & 117 & 117 & 113 & 103 & 108 & 113 & 121 \\
Berat Akhir Udang (gr) & 20,4 & 19,6 & 19,23 & 16,94 & 19,23 & 18,8 & 22,7 \\
$\begin{array}{c}\text { Laju Pertumbuhan Harian } \\
\text { (gr/hari) }\end{array}$ & 0,21 & 0,20 & 0,22 & 0,22 & 0,24 & 0,22 & 0,24 \\
\hline
\end{tabular}


Survival Rate

Kelulushidupan udang berpengaruh terhadap nilai produksi udang budidaya. Perbedaan survival rate pada masing-masing petakan tambak dapat dilihat pada Gambar 1.

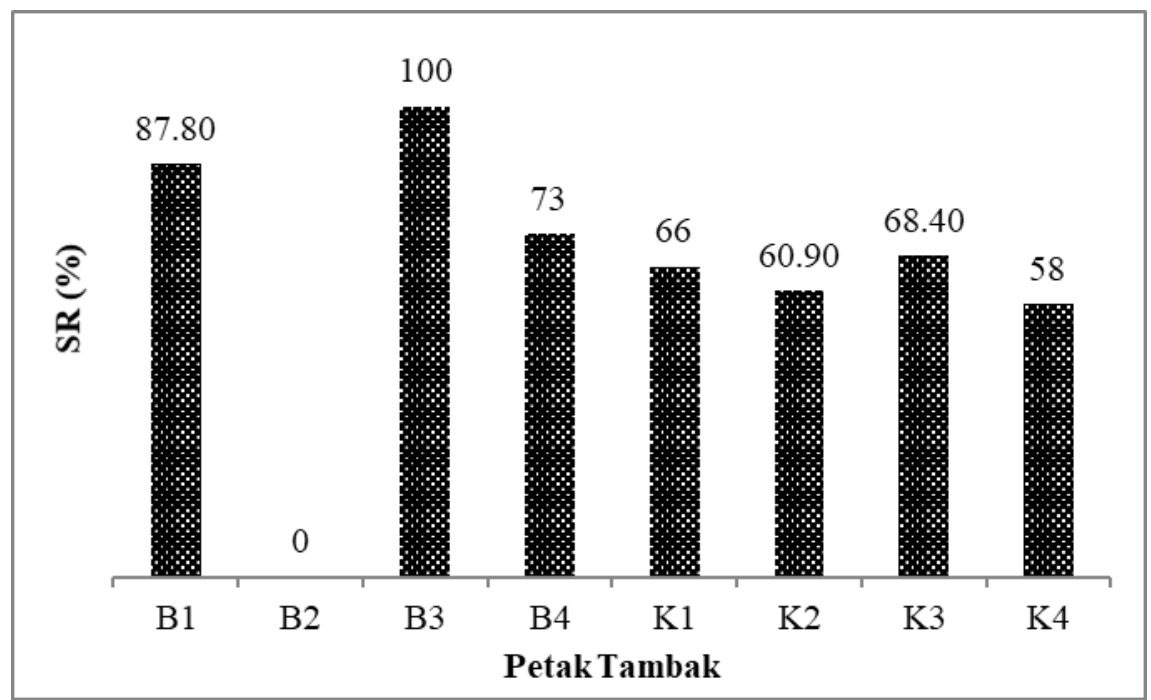

Gambar 1. Kelulushidupan udang pada masing-masing petak tambak

Dari Gambar 3 di atas dapat diketahui bahwa SR terendah adalah pada petak tambak B2 yaitu $0 \%$ dan SR tertinggi adalah pada petak tambak B3 yaitu $100 \%$. SR rendah pada tambak B2 terjadi akibat serangan WSSV yang mengakibatkan kematian hingga $100 \%$. Serangan jenis virus ini ke dalam tambak terjadi akibat penularan dari tambak sebelah yang sebelumnya terserang WSSV dan membuang air tambak ke saluran air.

WSSV merupakan salah satu penyakit yang menjadi penyebab utama penurunan produksi udang vaname (Hidayani et al., 2015). Penanganan kasus udang vaname yang terserang WSSV belum banyak dilakukan oleh para petambak. Selama ini, penanganan udang yang terserang WSSV hanya dengan cara meningkatkan kekebalan tubuh udang dengan cara di vaksin (Rafiqie, 2014). Untuk mencegah serangan virus yang berbahaya, Subyakto et al. (2008), merekomendasikan sistem budidaya udang semi intensif dengan sirkulasi tertutup menggunakan probiotik agar kualitas lingkungan terjaga dan berkelanjutan.

\section{Biomassa}

Biomasa merupakan total berat udang atau total produksi udang dalam satu siklus masa budidaya. Biomasa diperoleh dari menjumlahkan hasil panen parsial dan total. Perbedaan biomasa pada masing-masing petakan tambak dapat dilihat pada Gambar 2. Biomasa terendah adalah pada petak tambak $\mathrm{B} 2$ yaitu $0 \mathrm{Kg}$ dan biomasa tertinggi adalah pada petak tambak B3 yaitu 2144,9 Kg. Tinggi rendahnya biomasa tergantung dari nilai berat udang rata-rata saat panen dan tingkat kelulus hidupan udang. Semakin tinggi biomasa maka akan semakin baik karena akan berdampak pada pendapatan petambak. 


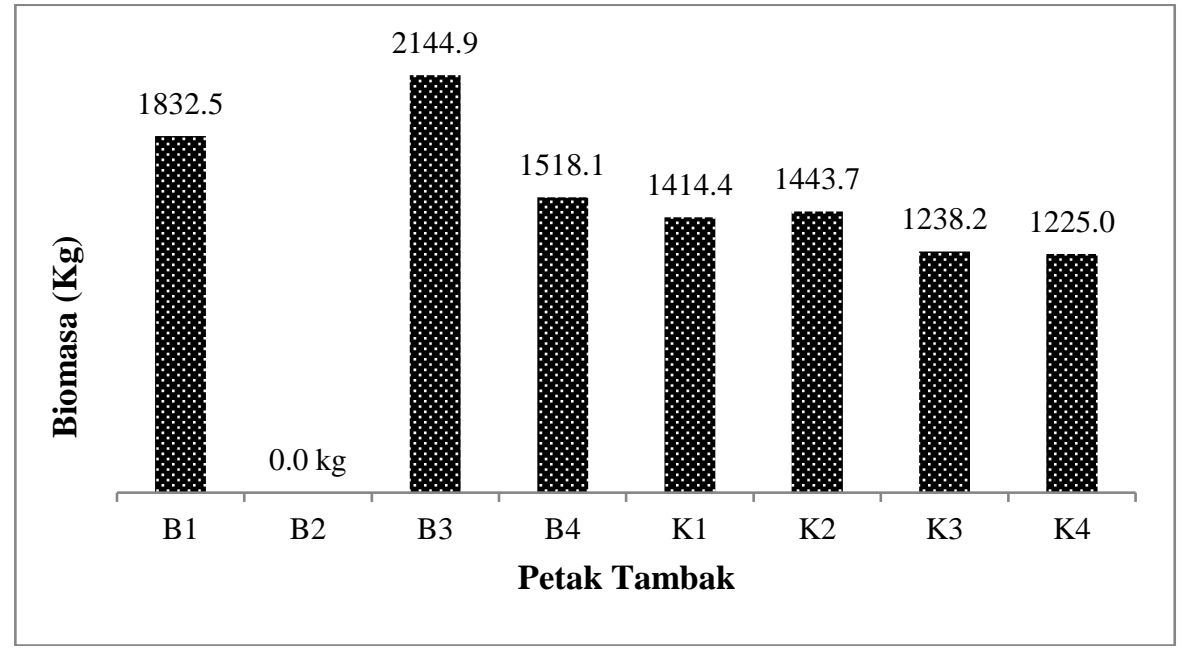

Gambar 2. Biomassa pada masing-masing petak tambak

Konversi Pakan

Perbedaan konversi pakan pada masing-masing petakan tambak dapat dilihat pada Gambar 3. Petak tambak B2 mengalami kematian $100 \%$ sehingga tidak didapatkan data FCR. Dari gambar diatas dapat diketahui bahwa FCR terendah adalah pada petak tambak B3 yaitu 1,6 dan FCR tertinggi adalah pada petak tambak $\mathrm{K} 1$ yaitu 2,49. Artinya, butuh 1,6 2,49 $\mathrm{kg}$ pakan untuk menghasilkan 1 $\mathrm{kg}$ daging udang. Nilai FCR pada penelitian ini diatas angka maksimal yang disebutkan Supono dan Wardiyanto (2008) yaitu 1,4. FCR yang terlalu tinggi mengindikasikan terjadi kelebihan jumlah pemberian pakan (over feeding). Over feeding tidak selalu menyebabkan pertumbuhan udang tinggi namun tetap berdampak pada tingginya beban limbah akibat sisa pakan dan kotoran udang.

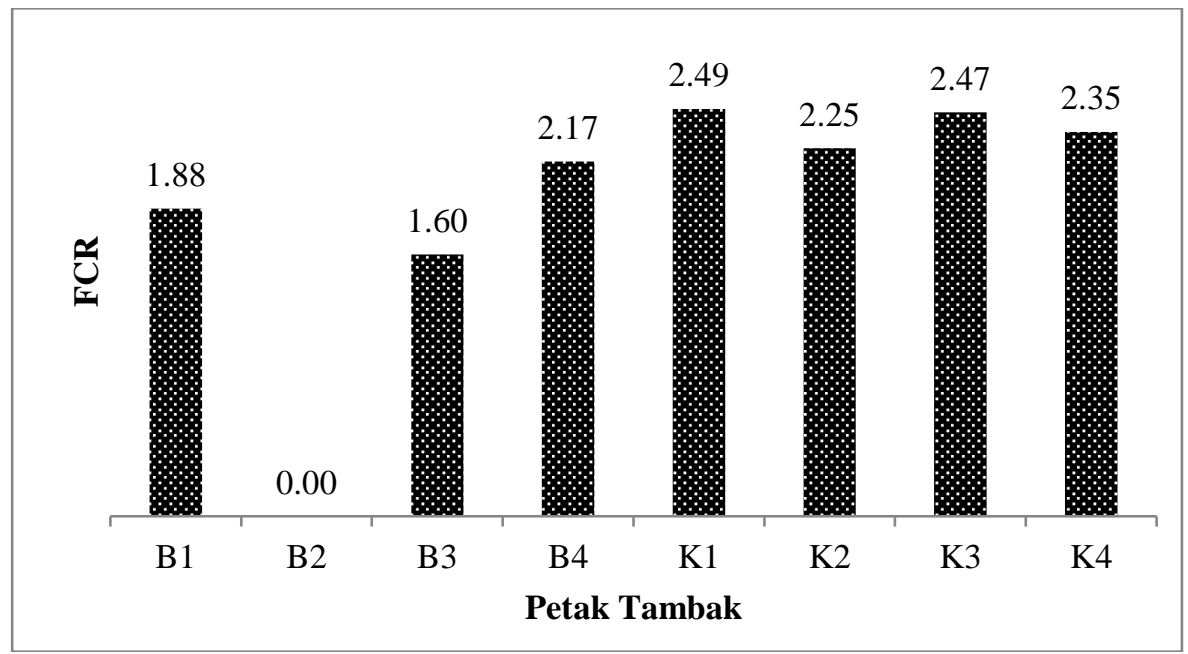

Gambar 3. FCR pada masing-masing petak tambak 


\section{Kualitas Air}

Kualitas air selama pemeliharaan pada masing-masing petakan tambak dapat dilihat pada Tabel 3. Tabel di datas menunjukkan bahwa beberapa parameter kualitas air ada yang berada pada kisaran optimal untuk pertumbuhan dan ada yang tidak ideal untuk kehidupan udang. Kualitas air pada media budidaya yang diukur seperti oksigen terlarut (5,0-5,3 mg/l), salinitas $(13,2-22,8 \mathrm{ppt})$ dan suhu $\left(29,9-30,1^{\circ} \mathrm{C}\right)$ berada pada kondisi normal, namun kecerahan $(<40 \mathrm{~cm})$, $\mathrm{pH}(<7)$, dan amonia $(0,029-0,031$ ppm) berada pada kondisi yang kurang ideal. Fluktuasi beberapa parameter kualitas pada media budidaya diakibatkan oleh kondisi cuaca, limbah organik dalam tambak dan belum stabilnya tanah konstruksi tambak. Perbaikan kualitas air akibat limbah organik dapat melibatkan bakteri menguntungkan yang ada dalam tambak atau penambahan dari luar. Herdianti et al., (2015) menyebutkan bahwa penambahan konsorsium bakteri menguntungkan seperti Nitrosomonas sp., Nitrobacter sp., Bacillus sp., dan Lactobacillus plantarum mampu menurunkan kadar ammonia-N sampai $96 \%$ serta menekan populasi bakteri merugikan seperti Vibrio sp.

\section{Kesimpulan dan Saran}

Dari data yang diperoleh dapat disimpulkan bahwa performa budidaya udang vaname semi intensif di tambak percontohan kurang memuaskan dilihat dari munculnya serangan white spot syndrome virus (WSSV) yang menyebabkan kematian hingga 100\% dan nilai FCR yang tinggi. Performa terbaik di petak B3 dilihat dari nilai FCR, SR dan biomasa yang lebih tinggi dibandingkan petakan lain. Performa budidaya udang vaname lebih baik pada Kelompok Petambak Sido Makmur dibandingkan Kelompok Petambak Lestari Gemilang dilihat dari produktivitasnya.

\section{Daftar Pustaka}

Bank Indonesia. 2015. Kajian Ekonomi dan Keuangan Regional Provinsi Lampung Triwulan II Tahun 2015. Kantor Perwakilan Bank Indonesia Provinsi Lampung.

Hidayani, A.A., Asmi C.M., Bunga R. T., dan Achmad, F.F. 2015. Deteksi Distribusi White Spot Syndrome Virus pada Berbagai Organ Udang Vaname (Litopenaeus vannamei). Jurnal Ilmu Kelautan dan Perikanan Torani Vol.25 (1) April 2015: 1-6.

Herdianti, L., Soewardi, K., Hariyadi, S. 2015. Efektivitas Penggunaan Bakteri Untuk Perbaikan Kualitas Air Media Budi Daya Udang Vaname (Litopenaeus vannamei) Super Intensif. Jurnal Ilmu Pertanian Indonesia (JIPI), Desember 2015 Vol. 20 (3): 265 271.

KKP. 2013. Statistik Volume Produksi Udang 2009-2013. Direktorat Jenderal Perikanan Budidaya. Kementerian Kelautan dan Perikanan.

Rafiqie, M. 2014. Penyakit Udang Vaname (Litopenaeus Vannamei) di Tambak PT Tanjung Bejo, Pajarakan Kabupaten Probolinggo. Samakia: Jurnal Ilmu Perikanan Volume 5, No. 1, Februari 2014 ISSN : 2086-386 1. 
Subyakto, S., Dede, S., Afandi, M., dan Sofiati. 2008. Budidaya Udang Vannamei (Litopenaeus vannamei) Semi intensif dengan Metode Sirkulasi Tertutup untuk Menghindari Serangan Virus. Berkala Ilmiah Perikanan Vol. 3 No. 1, April 2008.

Supono dan Wadiyanto. 2008. Evaluasi Budidaya Udang Putih (Litopenaeus vannamei) dengan Meningkatkan Kepadatan Tebar di Tambak Intensif. Seminar Hasil Penelitian \& Pengabdian kepada Masyarakat Universitas Lampung. Hal 237-242. 